"Mircea cel Batran" Naval Academy Scientific Bulletin, Volume XIX - 2016 - Issue 1

Published by "Mircea cel Batran" Naval Academy Press, Constanta, Romania // The journal is indexed in:

PROQUEST / DOAJ / DRJI / JOURNAL INDEX / I2OR / SCIENCE LIBRARY INDEX / Google Scholar / Crossref /

Academic Keys / ROAD Open Access / OAJI / Academic Resources / Scientific Indexing Services / SCIPIO

\title{
THE INTERACTION BETWEEN EXPLOSIVE DETONATION, MARINE MINE WALL AND WATER
}

\author{
Gheorghe ICHIMOAEI ${ }^{1}$ \\ Octavian TĂRĂBUŢĂ ${ }^{2}$ \\ Cătălin-Paul CLINCI ${ }^{3}$ \\ Aurel GHERGHINA ${ }^{4}$ \\ ${ }^{1}$ Advanced instructor PhD., "Mircea cel Batran" Naval Academy \\ ${ }^{2}$ Assistant professor PhD., "Mircea cel Batran" Naval Academy \\ ${ }^{3}$ Lecturer PhD., "Mircea cel Batran" Naval Academy \\ ${ }^{4}$ Dr. Ministry of National Defence, Bucharest, Romania
}

Abstract: In this paper we made a theoretical study on the transfer of the shock wave generated by the detonation of an explosive charge in to the water and we established a procedure which in necessary in order to evaluate the effects produced on underwater objects and ships hulls.

Keywords: detonation, marine mine, shock wave, detonation products.

\section{Fundamentals}

When an explosive charge is detonated, the shock wave is moving in the environment (water) and, at one moment, will be in the same position with the external environment interface.

When the explosive charge of a mine is detonating, two phenomenon appears: the shock wave, which is induced in mine body and the shock wave propagation. The shock wave propagation through surrounding environmental is usually modeled without take in to consideration the body of mine. According with this model, the process could be divided in two stages:

- The interaction between the mine body and environment (water);

- Transmission of produced shock wave in to the water.

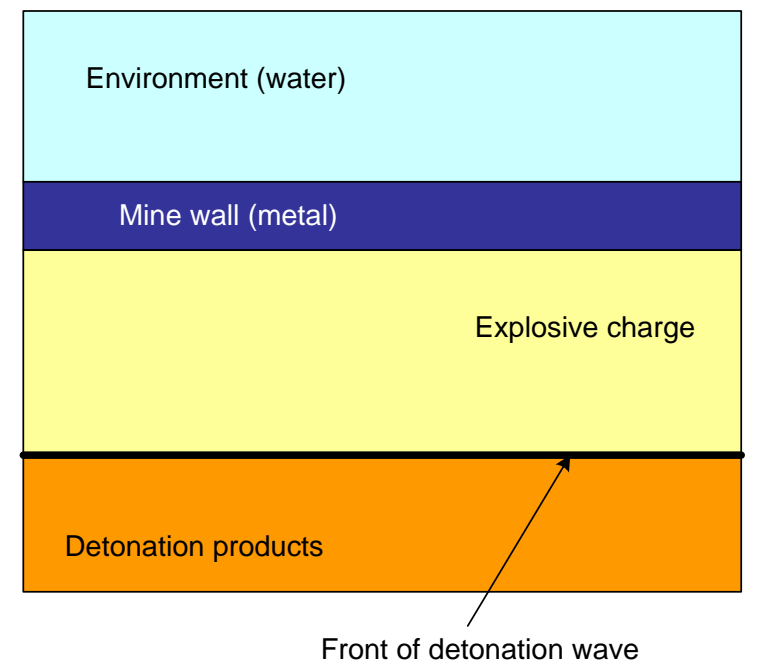

Figure 1. The shock wave transmission in to surrounding environment
The analysis of interaction between detonation, mine body and environment In order to perform this analysis we made de following assumptions:

- pressures and speeds of the environments which are exposed to the shock wave action are very high and thus it is possible to consider non-viscous fluids form;

- detonation wave front will attack frontal the marine mine wall, which is considered plan;

- detonation wave front is considered plan and will induce planed shock waves;

Shock states calculation will be performed for the first phase of the transmission process. The phenomenon will not be evaluated for high durations, due to the complexity of relaxations and intersection between different bundles of relaxation waves. This difficulty is based on ignorance of the properties of materials at very high pressures.

\section{The detonation of explosive charge}

The detonation wave is initiated as a result of a shock wave which is produced by a shock generator (detonator). Detonation wave is travelling through the explosive with speed $D$ and has a plane form. Behind the front are the detonation products, which have the following characteristics: pressure $p_{C J}$ and material speed $u_{C J}$. 
"Mircea cel Batran" Naval Academy Scientific Bulletin, Volume XIX - 2016 - Issue 1

Published by "Mircea cel Batran" Naval Academy Press, Constanta, Romania // The journal is indexed in: PROQUEST / DOAJ / DRJI / JOURNAL INDEX / I2OR / SCIENCE LIBRARY INDEX / Google Scholar / Crossref /

Academic Keys / ROAD Open Access / OAJI / Academic Resources / Scientific Indexing Services / SCIPIO

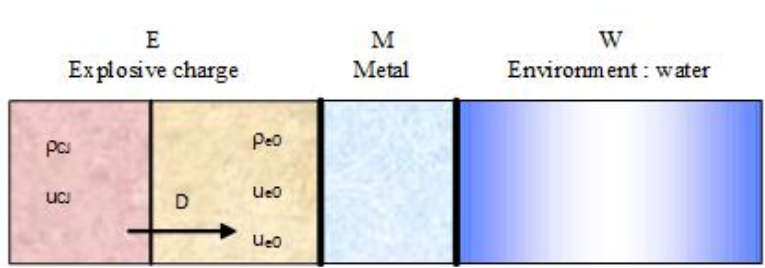

Figure 2. Interaction between explosive detonation/ marine mine wall/environment (water)

Immediately, the detonation products are expanded. The pressure variation in time could be represented as in figure 3.

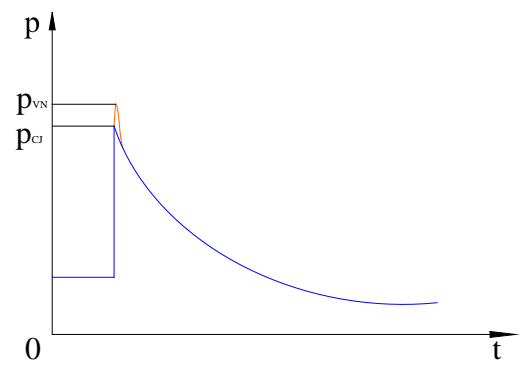

Figure 3 Pressure variation in time

\section{Generating shock in the marine mine wall}

Once the detonation wave front reaches the interface between explosive and marine mine wall, a new equilibrium it established. Using a graphic method to evaluate the equilibrium states, we have the possibility to compute the parameters of induced shock in plaque and for reflected wave which could be a shock wave or an expanded wave.

The reflected wave type is determined by position of C-J point related with intersection point between shock polar curve for material of the plaque (marine mine wall) and the detonation products isentropic curve, as it is shown in figure 4.

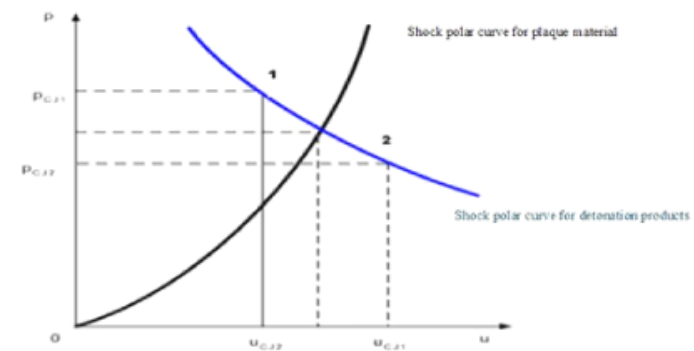

Figure 4 Determining the shock characteristics

In case 1, where parameters for detonation products are ${ }^{\left(p_{C-J_{1}} ; u_{C-J_{1}}\right)}$, the reflected wave is an expanded wave. In case 2, where parameters for detonation products are $\left(p_{C-J_{2}} ; u_{C-J_{2}}\right)$, the reflected wave is a shock wave. In both situations the parameters for metallic plaque will be $\left(p_{1} ; u_{1}\right)$ and shock wave speed is $D_{M_{01}}$.

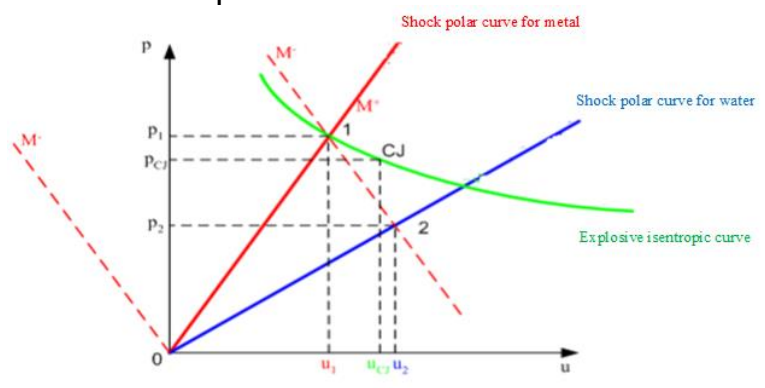

Figure 5 Equilibrium states at an explosive charge detonation in contact with metallic wall of marine mine and environment (water)

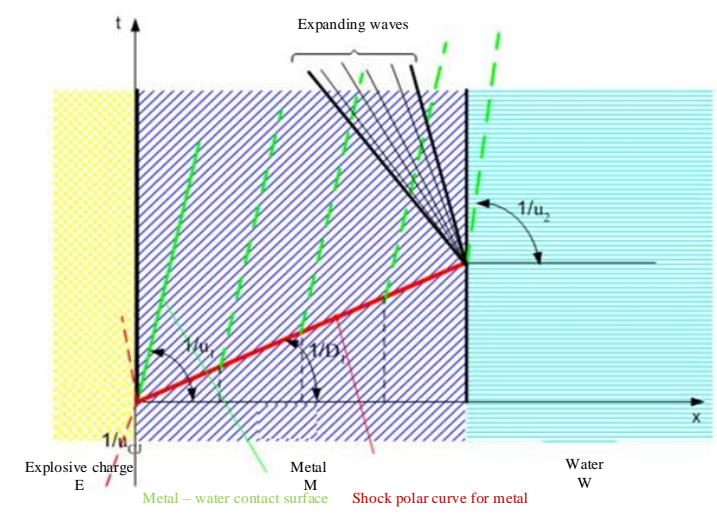

Figure 6 Graphic representations of expanded waves and shock waves

In case 1 , the induced shock in metallic plaque is described by $\left(p_{1} ; u_{1}\right)$, which are determined by graphic method (the interaction between direct shock polar curve, with parameters $\beta=0, u_{0}=0$ and the detonation products isentropic curve ).

The shock wave speed (shock wave induced in metallic plaque when the detonation occurs) is described by:

$D_{M_{01}}=C_{M}+S_{M} u_{1}$

A shock wave with $\left(p_{1} ; u_{1}\right)$ parameters is reflected in the detonation products and we could write:

$D_{E_{C J 1}}=C_{E_{1}}+S_{E}\left(u_{1}-u_{C J}\right)$

Shock transmission mechanism from marine mine wall to water 
"Mircea cel Batran" Naval Academy Scientific Bulletin, Volume XIX - 2016 - Issue 1

Published by "Mircea cel Batran" Naval Academy Press, Constanta, Romania // The journal is indexed in: PROQUEST / DOAJ / DRJI / JOURNAL INDEX / I2OR / SCIENCE LIBRARY INDEX / Google Scholar / Crossref /

Academic Keys / ROAD Open Access / OAJI / Academic Resources / Scientific Indexing Services / SCIPIO

When the shock wave front is reaching the interface between metallic plague (marine mine wall) and water, a new equilibrium state will be established.

The new equilibrium state (2) is obtained at the intersection of shock polar curve of water, which is passing from state 0 and the symmetric polar curve of metallic plaque, which is passing from state 1 , as you can see on figure 5 .

Equilibrium state 2 is described by $\left(p_{2_{A p}} ; u_{2_{A p}}\right)$ parameters and induce a shock wave in water and some expanded waves in metallic plaque.

For example, in figure 7 we drew the detonation products isentropic curve and shock polar curve for water and metallic plaque (marine mine wall), when a TNT detonation occurs. After TNT detonation a shock wave in generated and this shock wave is transmitted to marine mine wall. Equilibrium is realized in state 1 and the induced shock in marine mine wall is described by $\left(p_{1} ; u_{1}\right)$. When shock wave is passing from marine mine wall to water, the equilibrium state 2 will be done.

Equilibrium state 2 is described by $\left(p_{2} ; u_{2}\right)$. The equilibrium states parameters are written in Table no.1.

Table no. 1 Pressure and speed values at the interface between marine mine wall - water

\begin{tabular}{|l|l|l|l|l|l|}
\hline \multirow{2}{*}{ No. } & Material of & \multicolumn{2}{|c|}{$\begin{array}{l}\text { Equilibrium } \\
\text { marine mine }\end{array}$} & \multicolumn{2}{c|}{$\begin{array}{l}\text { Equilibrium } \\
\text { state 1 1 }\end{array}$} \\
\cline { 3 - 6 } & wall & $\mathrm{p}_{1}$ & $\mathrm{u}_{1}$ & $\mathrm{p}_{2}$ & $\mathrm{u}_{2}$ \\
\hline 1 & STEEL & 330 & 700 & 55 & 1400 \\
\hline 2 & ALUMINUM & 240 & 1250 & 100 & 2000 \\
\hline 3 & PERSPEX & 145 & 2100 & 125 & 2250 \\
\hline
\end{tabular}

When the marine mine wall is made with STEEL and ALUMINUM, the equilibrium state 1 pressure will be $p_{1 S T}=330$, respectively $p_{1 A L}=240$ kbar, and in the explosive charge a shock wave will be reflected, because $p_{1}>p_{c J}\left(p_{c J}=155\right.$ kbar).

When the marine mine wall is made with PERSPEX, the equilibrium state 1 pressure will be $\mathrm{p}_{1 \mathrm{PER}}=145 \mathrm{kbar}$ and in the explosive charge an expanded wave will be reflected, because $p_{1}<$ pcs.

If the marine mine wall is made by STEEL or ALUMINUM, the equilibrium state 2 will be described by $\mathrm{p}_{2 \mathrm{ST}}=55 \mathrm{kbar}$, respectively $\mathrm{p}_{2 \mathrm{AL}}=$ $100 \mathrm{kbar}$, and in the marine mine wall will be reflected some expanded waves.
If the marine mine wall is made by PERSPEX, the equilibrium state 2 pressure will be $\mathrm{p}_{2 \mathrm{PER}}=125$ kbar, and in the marine mine wall will be reflected some expanded waves. We could observe that the transmitted shock in to the water in more damped, as the material on marine mine wall in less compressible compared to water.

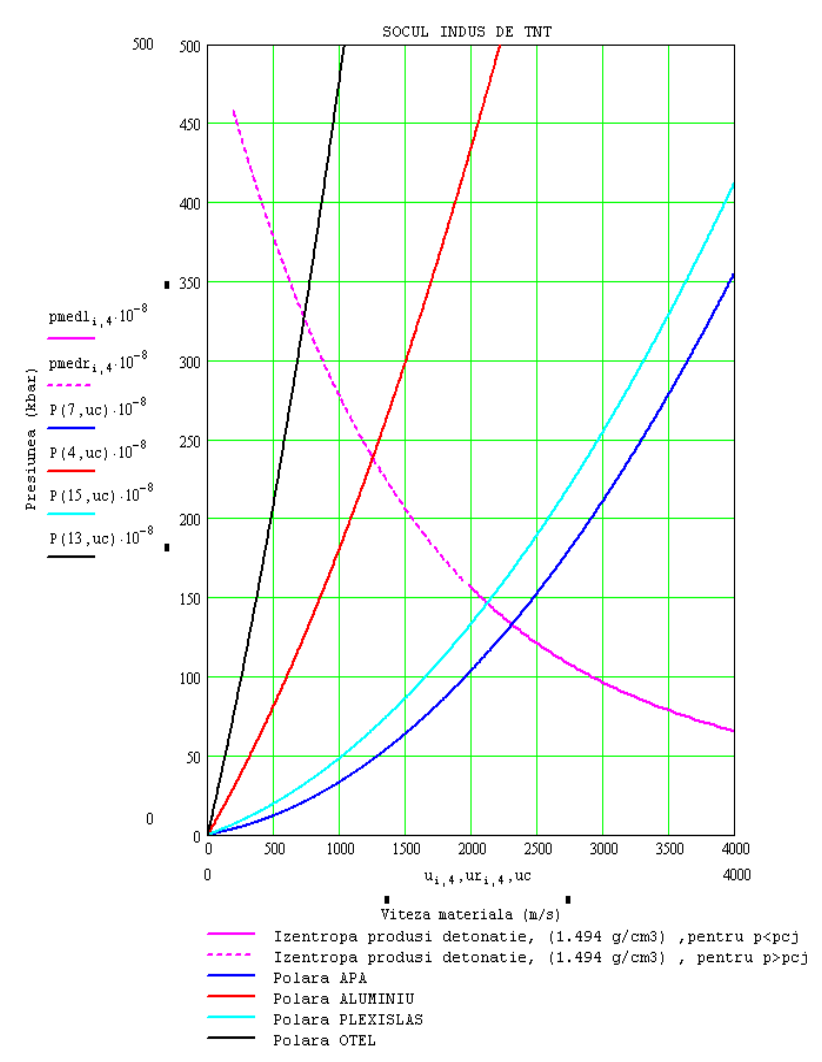

Figure 7 Shock parameters for TNT - marine mine wall ensemble

In addition, after the reflection of expanded wave, the marine mine wall is less accelerated. So, the water brakes the movement of marine mine wall, and pressure in shock wave front will decreased. When the marine mine wall is made with PERSPEX, the pressure and speed values for the two equilibrium states are quietly similarly, and the shock wave is not damped by water, because the shock properties for PERSPEX and water are almost the same.

\section{BIBLIOGRAPHY}

[1] BODIN C., Explozivi, Date termochimice, Editura Academiei Militare, Bucureşti, 1974.

[2] BODIN C., Fizica explozivilor, Editura ATM, Bucureşti, 1972.

[3] BERGER J., VIARD J., Fizica explozivilor solizi, Dunod, 1968.

[4] ANDREEV K., BELEAEV A. I., Teoria substanţelor explozive, Moscova, 1960. 
"Mircea cel Batran" Naval Academy Scientific Bulletin, Volume XIX - 2016 - Issue 1

Published by "Mircea cel Batran" Naval Academy Press, Constanta, Romania // The journal is indexed in:

PROQUEST / DOAJ / DRJI / JOURNAL INDEX / I2OR / SCIENCE LIBRARY INDEX / Google Scholar / Crossref /

Academic Keys / ROAD Open Access / OAJI / Academic Resources / Scientific Indexing Services / SCIPIO

[5] ANDERSON D., Metode numerice aplicate în hidrodinamică şi transfer termic, Moscova, 1990.

[6] CHERECHES T., OPREA G., STEFAN S., BERBENTE I., Metode numerice în rezistenţa materialelor şi mecanică, Editura Academiei Militare, Bucureşti,1985.

[7] CHERECHES T., BUNEA M., BUCNARU G., Muniţii. Noţiuni introductive. Substanţe explozive utilizate în producţia de muniţii. Materiale folosite în fabricarea muniţiilor. Parametri balistici ai muniţiei, Editura Academiei Tehnice Militare, Bucureşti, 1996.

[8] COLE R., Underwater explosion, Princeton University Press, 1948.

[9] GOGA D. A., Probleme speciale de detonică, Editura Academia Tehnică Militară, Bucureşti, 2004.

[10] GOGA D. A., ORBAN O., Fabricaţia şi proprietăţile substanţelor explozive, Editura Academiei Tehnice Militare, Bucureşti, 1997.

[11] GOGA D. A., Conception et realisation d'un générateur d'onde de choc plane par relévement de plaque, Rapport D. E. A. Poitiers, 1997.

[12] GOGA D. A., Contribuţii cu privire la sudarea prin explozie a plăcilor metalice subţiri, Teză de doctorat, Academia Tehnică Militară, Bucureşti, 1999.

[13] ICHIMOAEI, G., Contribuţii la cercetarea şi realizarea minelor marine şi fluviale utilizate pentru apărarea comunicaţiilor navale, Teză de doctorat, Bucureşti, 2006.

[14] NEME A., DAHAN N., Les Vemes Journées Détonique, Comportament des plaque métalliques épaisses á l'impact de cylinders, RSTD nr. 4, 1995, pag. 45-50.

[15] NITT̆ M., STERIE Ştefan, Curs de mecanică tehnică, Editura Academiei Militare, Bucureşti, 1974.

[16] ORBAN O., GOGA D., CHERECHEŞ T., Aspecte privind corelaţia dintre caracteristicile energetice ale unor substanţe chimice şi caracteristicile mecanice ale anvelopelor metalice, Sesiunea de comunicări ştiinţifice a Universităţii din Oradea, 2-4 iunie 1995. 